ISBN 978-93-84468-94-1

International Conference on Education, Business and Management (ICEBM-2017)

Bali (Indonesia) Jan. 8-9, 2017

\title{
Consumer Behavior on Purchasing Decision in Buying Sports Clothes in Saraburi Province, Thailand
}

\author{
Dr. Watchara Yeesuntes, Thanarak Buran \\ Post Gaduat school of business administration, Kasembundit University,Bangkok
}

\begin{abstract}
The primary purpose of this study is to determine consumer behavior and marketing mix factors affecting purchasing decision in buying sports clothes in Saraburi Province. Samples were 385 customers who previous buyers to buy sports clothing from the stores in Saraburi province by using a check list and rating scale questionnaire. The statistics used for data analysis were percentage, mean, standard deviation, Chi-Square test, and regression analysis.

On the basis of the results of this study, it could be concluded that most of respondents were males, age 2630 years old, bachelor degree graduated, single marital status, private company employees, and average monthly income 15,000-20,000 baht. Factors of personal different such as average income affected consumer behavior on purchasing decision in buying sports clothes in Saraburi Province. Marketing mix factors affecting purchasing decision on buying sports clothes in Saraburi Province which overall picture of opinions were in a high level when considering each aspect, such as products, prices, distribution channel, and marketing promotion. The test of hypothesis revealed that factors of marketing mix, such as fashionable products, wide range of prices, and easy access to stores correlated to consumer behavior on purchasing decision in buying sports clothes in Saraburi Province with overall picture of opinions were in a statistical significant 0.05 level.

Recommendations from the study were to improve marketing strategy. Entrepreneur should offer a variety of clothing, fashionable style, material clothing quality, categorize products with the same type, attractive displays, appropriate prices with quality of clothes, and with knowledgeable salespersons.
\end{abstract}

Keywords: behavior, selection

\section{Introduction}

Currently, Thailand's textile industry have tendency to grow especially sports clothing products which are in trend. The Thai clothing factory was employed to produce sports clothing for World soccer games 2014, in Brazil. Thai clothing factories have been internationally recognized for potential of producing quality products which create benefit in fashion industries. Therefore, Thai sports clothing has been awaken and growth according to the reported of manager online news, 2557.

At present, an innovative of laser sewing of sportswear with seamless, no skin irritation which is one more reason that create added value to sportswear products. Sportswear Clothing are still the most popular for athletes and fans. Therefore, entrepreneur should take this opportunity to increase sales by developing marketing promotion strategy to persuade consumer to spend more on sports clothing. Part of that come from sports competition such as World soccer games what makes the sports clothing which tendency to growth. The world soccer games, what motivate consumer to purchase sports clothing for collection and souvenir. As introduction mentioned above, researcher was interested in studying consumer behavior and marketing mix factors affecting purchasing decision in buying sports clothes in 
Saraburi Province and collect this results from the study to produce a guideline for entrepreneur to develop marketing strategy in order to be benefited in the business.

\section{Concept, Theories of the Marketing Mix}

The 4Ps of marketing is a model for enhancing the components of your 'marketing mix' - the way in which you take a new product or service to market. It helps you to define your marketing options in terms of price, product, promotion, and place so that your offering meets a specific customer need or demand.

You just need to create a product that a particular group of people want, put it on sale some place that those same people visit regularly, and price it at a level which matches the value they feel they get out of it; and do all that at a time they want to buy. Then you've got it made!

There's a lot of truth in this idea. However, a lot of hard work needs to go into finding out what customers want, and identifying where they do their shopping. Then you need to figure out how to produce the item at a price that represents value to them, and get it all to come together at the critical time. But if you get just one element wrong, it can spell disaster. You could be left promoting a car with amazing fuel-economy in a country where fuel is very cheap; or publishing a textbook after the start of the new school year, or selling an item at a price that's too high - or too low - to attract the people you're targeting.

The marketing mix is a good place to start when you are thinking through your plans for a product or service, and it helps you avoid these kinds of mistakes.

"Marketing mix" is a general phrase used to describe the different kinds of choices organizations have to make in the whole process of bringing a product or service to market. The 4Ps is one way - probably the best-known way - of defining the marketing mix, and was first expressed in 1960 by E J McCarthy ${ }^{1}$. The 4Ps are: Product (or Service), Place, Price, and Promotion.

\section{Purpose of the study}

The primary purpose of this study is to determine consumer behavior and marketing mix factors affecting purchasing decision in buying sports clothes in Saraburi Province.

\section{Conceptual frameworks of the Study}

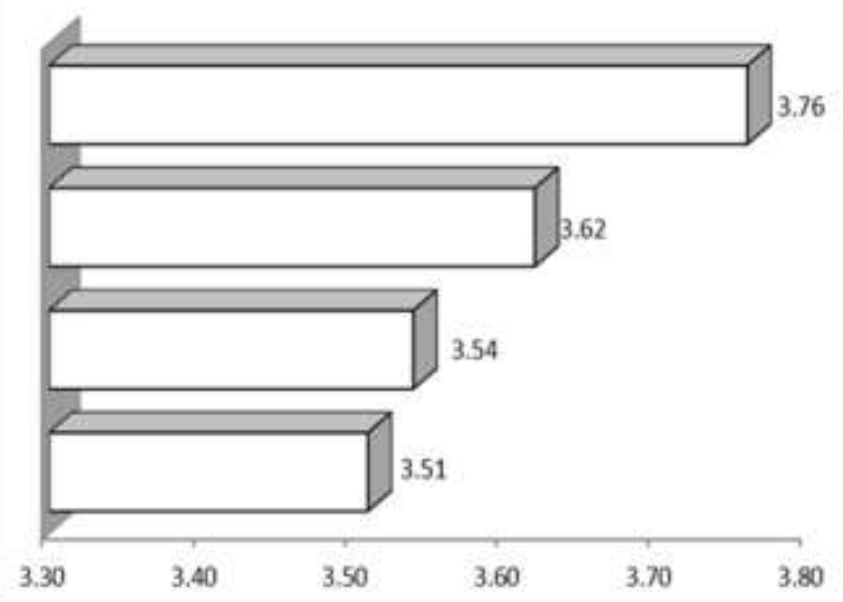

\footnotetext{
${ }^{1}$ McCarthy, Jerome E. (1960). Basic Marketing. A Managerial Approach. Homewood, IL: Richard D. Irwin.
} 

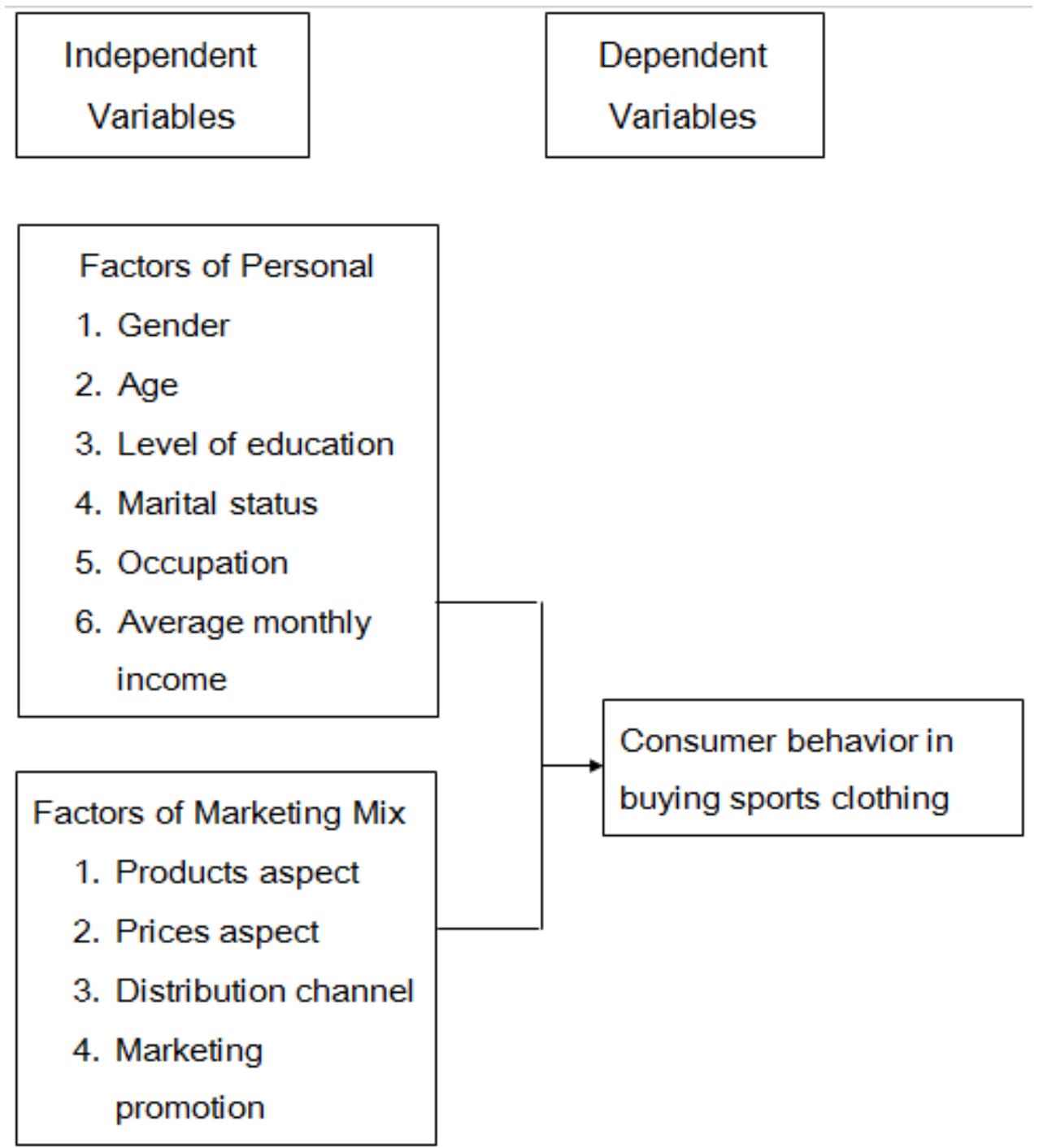

From above figure shows that consumer focused on marketing mix factors affecting purchasing decision in buying sports clothes in Saraburi Province with average picture of opinions at high level $(\bar{x}=3.61)$ consisted of following details:

Products aspect $(\bar{x}=3.76)$, prices aspect $(\bar{x}=3.62)$, distribution channel aspect $(\bar{x}=3.54)$, and marketing promotion $(\bar{x}=3.51)$, respectively.

From table 1: factors of personal different such as average monthly income was not affected consumer behavior on choosing sport clothing with significant level 0.05 . 
TABLE I: shows the test of hypothesis with regression value, correlation between factors of marketing mix and consumer behavior on choosing sport clothing.

\begin{tabular}{|c|c|c|c|c|c|c|}
\hline \multirow[t]{2}{*}{ Model } & \multicolumn{2}{|c|}{$\begin{array}{c}\text { Unstandardized } \\
\text { Coefficients }\end{array}$} & \multirow{2}{*}{$\begin{array}{c}\begin{array}{c}\text { Standardized } \\
\text { Coefficients }\end{array} \\
\text { Beta } \\
\end{array}$} & \multirow[t]{2}{*}{$\mathrm{t}$} & \multirow[t]{2}{*}{ Sig. } & \multirow[t]{2}{*}{ Results } \\
\hline & $\mathrm{B}$ & Std. error & & & & \\
\hline (constant) & .420 & .466 & & .902 & .370 & \\
\hline \multicolumn{7}{|c|}{ Prices aspect } \\
\hline Sport clothing style & .174 & .094 & .150 & 1.847 & $.049 *$ & $\begin{array}{l}\text { relationshi } \\
\mathrm{p}\end{array}$ \\
\hline Work quality & -.003 & .090 & -.002 & -.030 & .976 & No relation \\
\hline Available with all sizes & .088 & .106 & .076 & .830 & .409 & No relation \\
\hline Clothes durable color & .151 & .113 & .122 & 1.343 & .183 & No relation \\
\hline Comfortable fabric & -.026 & .124 & -.022 & -.211 & .834 & No relation \\
\hline Wide range of styles & .082 & .090 & .091 & .909 & .366 & No relation \\
\hline Well-known brand name & -.187 & .102 & -.192 & -1.83 & .071 & No relation \\
\hline \multicolumn{7}{|c|}{ Prices aspect } \\
\hline Appropriate prices styles & -.025 & .107 & -.023 & -.233 & .816 & No relation \\
\hline Appropriate prices to quality & .049 & .096 & .056 & .506 & .614 & No relation \\
\hline Prices bargaining & .108 & .103 & .118 & 1.050 & .297 & No relation \\
\hline Clearly prices labels & -.175 & .109 & -.165 & -1.60 & .113 & No relation \\
\hline Wide range of prices & .322 & .107 & .321 & 3.007 & $.004^{*}$ & $\begin{array}{l}\text { relationshi } \\
\mathrm{p}\end{array}$ \\
\hline \multicolumn{7}{|c|}{ Distribution channel } \\
\hline Easy access to shop & .228 & .113 & .199 & 2.008 & $.048^{*}$ & $\begin{array}{l}\text { relationshi } \\
\mathrm{p}\end{array}$ \\
\hline Conveniently travel & .263 & .104 & .254 & 2.539 & $.013^{*}$ & $\begin{array}{l}\text { relationshi } \\
\mathrm{p}\end{array}$ \\
\hline Interesting products display & .043 & .118 & .039 & .362 & .718 & No relation \\
\hline Fitting rooms & -.177 & .104 & -.179 & -1.70 & .092 & No relation \\
\hline Sizable shop & -.074 & .098 & -.088 & -.755 & .453 & No relation \\
\hline \multicolumn{7}{|c|}{ Marketing promotion } \\
\hline Free gift with purchased & .008 & .109 & .009 & .071 & .944 & No relation \\
\hline Servicing by salespersons & .124 & .108 & .136 & 1.148 & .255 & No relation \\
\hline Inform products by salespersons & .085 & .111 & .094 & .771 & .443 & No relation \\
\hline Advertising thru TV channel & -.043 & .116 & -.041 & -.368 & .714 & No relation \\
\hline Advertising thru printed media & .041 & .101 & .045 & .412 & .681 & No relation \\
\hline Discount prices & .137 & .108 & .141 & 1.268 & .209 & No relation \\
\hline Product guarantee & .062 & .114 & .058 & .545 & .588 & No relation \\
\hline
\end{tabular}

*statistical significant $<0.05$

From table 1 shows the results of hypothesis testing with regression value at significant level 005 and relationship between marketing mix factors with buying sports clothing habits in Saraburi province as followed details: wide range of prices, access to shop with convenient, convenient of purchasing, and stylish with significant level at 0.0040 .0130 .048 and 0.049 , respectively. It rejected main hypothesis $\mathrm{H} 0$ meaning marketing mix factors, such as wide range of prices, traveling and purchasing with convenient, stylish, and modern styles.

\section{Summary of study results}

The results were that marketing mix factors had impact on consumer behavior on choosing sports clothing in Saraburi Province.

Consumer contributed priority to the marketing mix that affecting consumer behavior on purchasing decision in buying sports clothes in Saraburi Province with average picture of opinion at high level which 
consisting of products aspect, prices, distribution channel, and marketing promotion was in high level, respectively.

Products aspect, results from the study revealed that overall picture of opinions was in high level when considered in details, such as stylish, a variety of designs, durable color, and comfortable fabric.

Prices aspect, results from the study revealed that overall picture of opinions was in high level when considered in details, such as wide range of prices, appropriate prices per style, bargaining prices, prices appropriate with quality, prices label clearly, respectively.

Distribution channel, results from the study revealed that overall picture of opinions was in high level when considered in details, such as purchasing convenient, attractive products display, easy access to shops, fitting room, and sizable stores.

Marketing promotion, results from the study revealed that overall picture of opinions was in high level when considered in details, such as advertising trough television station, information inform by salesperson, and advertising through printing media. In addition, factors as products guarantee, free gift with purchase, bargaining prices, service by personnel which were in medium level of the opinion.

\section{Suggestions for future research}

Suggestion for future research, study method should be in-depth interview by asking questions to entrepreneur regarding marketing strategy that they have used, and study of weak point and strength of sport clothing products.

\section{References}

[1] Kamolthip Srisooksai. (2556). Factors affecting consumer behavior on buying women clothing: Case study, Thesis, Master of Business Administration, Ratchaphat Phuket University.

[2] Kanyarat Cajchavari \& associate. (2537). Results of supplement food products advertising, Thesis, Chulalongkorn University.

[3] Dara Teprapan. (2542). Consumer behavior teaching Manual. Roongruang Sarn printing, Bangkok

[4] Damrongsak Chaisanit. (2542). Human resources management, Thaiwatanapanich printing, Bangkok.

[5] Thongchai Santivong. (2540). Consumer behavior marketing management. Thaiwatanapanich printing, Bangkok.

[6] Narasri Vaivanichkul \& Associate. (2545). Business research regulation. Chulalongkorn University Printing, Bangkok.

[7] Parinrak Sitanont. (2544). Consumer behavior analysis. Edison press-product.

[8] McCarthy, Jerome E. (1960). Basic Marketing. A Managerial Approach. Homewood, IL: Richard D. Irwin.

[9] Ratprapa Heamchinda. (2557). Marketing and grand sport product brand communication in Consumer point of view. NIDA, Bangkok.

[10] Vansiri Pankosol. (2542). The study of consumer behavior on choosing Land \& Houses homes in Chiang Mai, Thesis, Maejo University. 